\title{
The Gospel of Divine Mercy in King Lear
}

\section{ABSTRACT}

The paper discusses Shakespeare's preoccupation with the Christian notions of divine love, forgiveness and justice in The Tragedy of King Lear. In my reading I employ Jean-Luc Marion's phenomenological reflection on the givenness of love and Hans-Urs von Balthasar's theology of Paschal mystery. I take issue with the Marxist and existentialist interpretations of Shakespeare's tragedy which prevailed in the second half of the $20^{\text {th }}$ century. My aim is not a simple recuperation of the "redemptionism" of the play, but an in-depth consideration of Christian allusions in the play which may tie love and forgiveness to justice and throw light on the ending of King Lear.

Keywords: William Shakespeare, King Lear, gift, mercy, forgiveness. 
The reader's first encounter with the greatest Elizabethan playwright is usually connected with his treatment of revenge. One of Shakespeare's earliest plays, Titus Andronicus, is, perhaps, also the bloodiest tragedy he ever wrote. Schoolchildren get to know Shakespeare by reading the story of innocent love destroyed by family feud, Romeo and Juliet. Shakespeare's best-known work, Hamlet, includes all the elements found in Thomas Kyd's Spanish Tragedy: insidious crime, madness, revenge and a stage performance which serves the avenger's dark purpose. Some people, when they see Mel Gibson starring as the Danish Prince in Franco Zeffirelli's film adaptation (1990), may be inclined to say: "At last, the right man for the task ... the actor who played Mad Max should do the job better than Laurence Olivier." The enduring popularity of revenge stories reveals the adamant logic of evil, which a contemporary philosopher, Jean-Luc Marion, has neatly described in the following way:

For evil, which appears to me only in its attack against me, calls for only one response-my own attack, intended to suppress it in return. Suppressing the cause of the evil, amounts, first of all, to pleading my cause against it. At the last, the desire for revenge responds to each evil. (2)

Because we all are only too well acquainted with the indisputable facticity of the pain inflicted on us by evil-the pain "short of all delusion," as Marion says-we are all potential avengers, and this is why we are inclined to take the avenger's side.

At the same time, however, careful readers of Shakespeare must quickly realize that over the course of his oeuvre the Bard strives to tell us something completely different from what is told by the authors of Roman, Elizabethan and Hollywood revenge stories. State violence and private revenge bring Titus's world to ruin; the families of the star-crossed lovers are reconciled in mourning over their deaths; and Hamlet is forced to learn that even Cain's crime cannot be avenged with impunity, for "whosoever slayeth Cain will suffer vengeance seven times over" (Gen. 4:15). In her contribution to a volume of essays published under the meaningful title Love and Forgiveness for a More Just World (2015), Regina Schwartz stated that "throughout the corpus of Shakespeare, revenge is suspect" (54). This argument was developed in her book Loving Justice, Living Shakespeare (2016), where she claims once again that Shakespeare not only warned his audiences against revenge, but pleaded for justice restored by love: 
"Shakespeare's plays not only condemn revenge, they endorse forgiveness. In Shakespeare ... forgiveness is tied to the recognition or rediscovery of love" (113).

Perhaps the play which best exemplifies such an abundance of merciful love is King Lear. Schwartz surely captures the spirit of the play when she writes: "While the play is not set in a Christian context, the endorsement of the biblical tradition that elevates love to the highest good is unmistakable" (Loving Justice 47). This statement shows that the shift toward an emphasis on the metaphysical void and overwhelming despair in the interpretations of King Lear which occurred in the second half of the $2^{\text {th }}$ century was neither final nor conclusive. Existentialist, sceptical and materialist readings may have suited the spirit of their time, but they certainly failed to do justice to Shakespeare's text. This does not mean that we may now turn a blind eye to the severity of Lear's predicament by simply recuperating the "redemptionist" interpretation of the play, but we should certainly take into account its Christian context, and address Shakespeare's treatment of the chief paradox of Christianity, which is the scandal of the Cross. In this article, I aim to focus on Shakespeare's portrayal of love, justice and forgiveness, drawing on theological reflection on the mystery of the suffering, death and resurrection of Jesus Christ.

\section{WHAT IS LOVE?}

First and foremost, King Lear warns us against abuses of love. The first act of the play is structured around the contest designed by a king who does not know that devotion cannot be measured by public declarations and who forgets that true love does not boast, deal perversely, think evil or seek its own, and is not easily provoked to anger (1 Cor. 13:4-8). In the beginning of the play we also meet Gloucester, who unabashedly admits his preference for pleasure-seeking, adulterous love over marital constancy. In contradistinction to Lear's and Gloucester's false notions, Cordelia and the King of France point to a genuine understanding of love. Lear's youngest daughter resolves to "love and be silent" (1.1.62), suggesting the priority of deed over words in love; her future husband formulates an important negative definition of love, highlighting its uncompromising totality; its categorical dismissal of all conditions or expectations; and its absolute demand to sacrifice everything that may turn the lover's attention away from loving: "Love's not love / When it is mingled with regards that stand / Aloof from the entire point" (1.1.241). True love should be unconditional, unqualified and unadulterated. It opposes everything which violates its purity or threatens its wholeness. The person who loves must 
be perfectly honest before herself and others; must be committed to love itself and nothing else, not even to the object of her affection, so as to avoid idolatry. The same admonition against mingling pure substance with base additions resounds in the Fool's condemnation of preachers' empty verbosity and brewers' dishonesty, "when priests are more in word than matter / when brewers mar their malt with water" (3.2.81-82), which may allude to Goneril's and Regan's love contaminated with flattery and selfregard. This leads us, in turn, to the scene when Lear casts off his clothes as "lendings" which characterize "sophisticated," i.e. contaminated humanity (3.4.104). In human society, clothes make the man, as the proverb goes: the king, the priest, the artisan and the peasant are each recognized by their attire. But naked Edgar, whom Lear calls "the thing itself," shows the universal misery of the fallen human being as: "a poor, bare, forked animal" (3.4.105-106) in need of divine mercy. In the Bible, the just are not naked, but clothed in grace; they wear robes "washed ... in the blood of the Lamb" (Rev. 7:14). The adjective "forked," usually construed here as denoting a two-legged creature because of its similarity to a two-pronged fork, is also reminiscent of the serpent's "forked" tongue, and thus ties human material and spiritual destitution to the curse of Original Sin. Accordingly, the events in the play show the destructive influence of greed, avarice, pride and selfishness on the human understanding of love.

The Gospel contrasts human love with Christ's logion about the unconditional generosity and copiousness of divine charity:

Love your enemies ... that you may be children of your father which is in heaven: for he maketh his sun to rise on the evil and on the good, and sendeth rain on the just and on the unjust. For if ye love them which love you, what reward have ye?... Be ye therefore perfect, even as your Father which is in heaven is perfect. (Matt. 5:43-48)

Yet instead of an obvious reference to the Gospel, Shakespeare offers a clue so discreet, so unobtrusive that it can easily be overlooked, but when it is acknowledged, his play overwhelms us with an intimation of immeasurable love. So King Lear portrays love which neither entails great passion, nor can be reduced to an abstract idea or moral imperative, but manifests itself in tenderness "whose low sounds / Reverb no hollowness" (1.1.154-155). Once again, the reader may connect Kent's words with St. Paul's great Hymn to Love, where the apostle says that without charity he would be "sounding brasse or a tinkling cymbal" (1 Cor. 13:1), but the connection is so subtle it must wait for our recognition to shape our perception of the play. Shakespeare's portrayal of the third daughter as the embodiment of love-her name, Cor-delia is suggestive of the ideal or perfect heart (Foakes 
155) - may refer to the symbolic value of the number three, which in many cultures is associated with completeness, wholeness and harmony. This harmony is destroyed when the king banishes Cordelia and gives the coronet, which had been intended for her, to Albany and Cornwall, encouraging them to "part" it between them, and the two men simultaneously grasp at the diadem because they cannot divide it literally, which foreshadows the ensuing chaos in the kingdom. The play's focus on the purity of love also explains Cordelia's unyielding repudiation of her sisters' conformism in act 1. Goneril and Regan flatter their father on his demand, and in accordance with courtly routine. But it is precisely in such compliance with the ways of the world that love cannot compromise. Taking into account Christian tradition, we may furthermore associate Shakespeare's definition of love as the "entire point" and "the thing itself" with the biblical name of God as revealed in Exodus 3:13, "I am who I am," and recall also that in Christianity "love" is another name for God (1 John 4:8).

In the course of the play, both Gloucester and Lear are brought to utmost misery because of their own betrayals of true love, suffering the consequences of their folly and following the path outlined in Jean-Luc Marion's description of the adamant logic of evil. Lear rages against his two wicked daughters, swearing to take revenge, but, quite remarkably, he cannot define the character of that revenge. He gives vent to his anger and despair in a series of broken, chaotic sentences: "I will have such revenges on you both / That all the world shall-I will do such things- / What they are yet I know not, but they shall be / The terrors of the earth" (2.2.467469). The key phrase here is "I know not," as if Lear wanted to show that no words can render his pain and no punishment can compensate for his suffering. The entire world seems too small to harbour his pain, and so we watch his yearning for revenge pass beyond all limits. The protagonist's self-absorption is also visible in his complaint that he is "a man / More sinn'd against than sinning" (3.2.59-60), which alludes to Reformation concern with Original Sin, but which may also be seen as a distorted echo of the Lord's Prayer: "Forgive us our trespasses as we forgive those that trespass against us.”

Gloucester, on the other hand, seems resigned to despair, but if we return to Marion again, we shall hear the philosopher recognize in suicide the ultimate act of revenge: "Revenge can, like a flood engulfing the universe, reach every man, make of all humanity, and even God, a culprit and an adversary. ... He who commits suicide bars himself from the possibility of reconciliation" (11-12). Had he carried out his desperate plan, Gloucester would thereby have committed sin against love-this is at least how Christianity interprets premeditated and voluntary selfslaughter-but the loving care of his son, Edgar, prevents the disaster. 


\section{LOVE AND MERCY}

Love triumphs once again when Cordelia forgives her prodigal father. In the Bible, mercy is symbolized by the father's hurrying to welcome the lost son. The parable of the Prodigal Son shows that mercy is farsighted, kind, swiftfooted and welcoming: "[W] hen he was yet a great way off, his father saw him and, and had compassion, and ranne, and fell on his neck" (Luke 15:20). The gifts bestowed on the returning son, the robe, sandals, and especially the signet ring, symbolize the love that God lavishes upon a repentant sinner. Through these gifts the Prodigal is restored to his status as son, and Cordelia insists that her father is restored to his royalty by making servants put a "fresh garment" on him before we see him again on stage (Snyder 362 ). ${ }^{1}$ Untidy appearance was suggestive in Shakespeare's theatre of mental disarray, but in the case of Lear the "fresh garment" denotes more than the end of his folly: it is a token of redemption and a foreshadowing of the new creation proclaimed in the book of Revelation. This eschatological perspective, as I shall argue, is crucial for a reading of King Lear.

Critics who draw our attention to the echoes of the parable of the Prodigal Son in Shakespeare's play have also noted the precedence of grace in the moment of reconciliation between Lear and Cordelia, and the correspondingly absolute character of the forgiveness offered by the king's youngest daughter. When Lear's beloved daughter cuts short the king's complaint about the wrongs inflicted on him by her elder sisters with the soothing "no cause, no cause" (4.5.55), she is expressing two things simultaneously: not only that Lear should no longer blame himself for the offences which he committed in the past, but also that love needs no alleged reason, "no cause," to forgive. Wilson Knight argues that Cordelia "represents the principle of love" in the play (124). John Francis Danby, who conducted an allegorical exegesis of the text, claimed that "tropologically she is Charity who suffereth long and is kind" and "anagogically the redemptive principle itself" (201). It may be worth noting in this context that the word "anagogy," which refers to the spiritual sense of an allegorical text, connotes an upward movement: climb or ascent, thereby suggesting that in the act of reading the reader's thought are lifted to heaven. Since anagogy denotes the last of the four senses of scripture and relates to the glorious mysteries to be revealed at the end of time, Danby linked Cordelia to Christ the Redeemer. In a similar vein, Richard Matthews noted that Lear's youngest daughter should be viewed as a symbol of the "love unquantifiable, love unpredictable, love unreasonable" which embraces the

1 The reader may note here the connection with the parable of the wedding banquet in Matthew 22.1-14, where a guest not wearing a wedding garment is removed from the celebration. I thank Jean Ward for bringing this allusion to my attention. 
world of the play (28). We may also recall here Joseph Holmes Summers's illuminating remark that love is Cordelia's "astonishing essence" (113; cf. also Battenhouse and Battenhouse 464). In our day, other critics add further evidence in favour of a Christian interpretation of the play. Robert Lanier Reid brings to our attention "medieval dramas and narratives of Christ's Passion" as "prototypes for the tortured body that is central to King Lear" (74). Similarly, R. V. Young reminds us that Cordelia, like Christ, was hanged on a tree and quotes the testimony of an unnamed gentleman, who tells Lear that she "redeems nature from the general curse / Which twain have brought her two," suggesting that "twain" which is usually interpreted as referring to Goneril and Regan, may also denote Adam and Eve, responsible for the "general curse" of Original Sin. Last but not least, Young points to the scene of reconciliation, which, in his opinion, brings "hope for mortals who find that their own efforts to rectify the world by adhering to the law written in their hearts and exercising their own natural virtues are insufficient" (272). I doubt, as Lanier Reid does, whether Shakespeare would evoke "these powerful epiphanic images of the Passion-which Louis Martz finds central to Renaissance devotions and religious lyrics-only to enforce the most profoundly sceptical nihilism" (74), so I propose to call King Lear a tour de force of Christian theodicy, which resolves the problem of immeasurable suffering by an appeal to the immeasurable love of the triune God.

\section{LOVE AND JUSTICE}

Drawing our attention to Shakespeare's Christian upbringing and outlook, Regina Schwartz argues that "Shakespeare's understanding of justice flows not only from classical conventions, but also from biblical tradition, where forgiveness enables just restoration of an injured moral order and where love is bound to justice" ("Revenge, Forgiveness, and Love" 56). This is evident in the indictment directed by Cordelia against her elder sisters, when she pities her exiled father, saying: "Mine enemy's dog, / Though he had bit me, should have stood that night / Against my fire" (4.7.36-38). The focus falls here on the unforgivable inhumanity of Goneril and Regan, but what seems particularly relevant in Cordelia's utterance is the fact that she describes her anger as "fire," suggestive of divine wrath against the unjust. We may consider this utterance as inconsistent with Cordelia's image as the embodiment of patient, enduring and forgiving love, but in fact it only confirms that Shakespeare's play is informed by the Christian idea of "love bound to justice." One of the greatest theologians of the twentieth century, Hans-Urs von Balthasar pointed out the risk involved in an expurgated, 
sugar-coated understanding of divine mercy when he wrote: " $[\mathrm{I}] \mathrm{f}$ we are going to dismiss language about the wrath of God as 'anthropomorphism,' then the language of God's 'mercy' or 'patience' must also disappear for the same reason" (62). Balthasar concludes by saying that divine love "would be merely flaccid without God's angry displeasure toward the unloving" (62).

The Greek god of the sky, Zeus, was believed to hurl lightning bolts at liars and people who broke their oaths; in the Bible, one of Job's friends speaks about the thunder of God's voice which strikes fear into the heart of man (Job 37:3-4). The entire third act of King Lear takes place during a raging storm, but the rain, thunder and lightning affect the victims of injustice, not the perpetrators. Small wonder that the exiled king begins to question the ways of providence, asking Edgar to consider the "cause" of "the thunder." Some critics have interpreted this as a possible allusion to Aristophanes' mockery of divine justice in his comedy, The Clouds (Cantor 231). Yet instead of embracing Aristophanes' barefaced disbelief, Shakespeare's play challenges the audience with a portrayal of the humanity which does not love Love.

Judy Kronenfeld has interpreted Cordelia's outburst as indicative of the general "neglect of charity in the world of the play" (174). Parents do not love children; children do not love parents; the rich do not show charity to the poor. King Lear shows a world populated by "poor naked wretches"; "houseless heads"; men, women and children with "unfed sides"; and vagabonds so badly dressed that their shabby clothing becomes quintessential "looped and windowed raggedness" (3.4.30-31). Both Lear and Gloucester begin to acknowledge the misery of the poor when they endure poverty themselves, but their reflection is rooted in Aquinas's doctrine of charity, which demanded that goods beyond one's need to keep oneself and one's family (bona superflua) should be given to those in need. Lear declaims: "Take physic, pomp, / Expose thyself to feel what wretches feel / That thou mayst shake the superflux to them / And show the heaven more just" (3.4.33-36); and Gloucester echoes: "So distribution should undo excess / And each man have enough" (4.1.73-74). Yet at the same time Lear admits that as a king who had the means to relieve the poor, he has "ta'en too little care of this" (3.4.32-33).

Marxist critics who stress this deficit of elemental charity in the play reduce the notion of "charity" to human compassion (at best) or institutionalized philanthropy (at worst), and focus on Shakespeare's condemnation of social inequality. Jonathan Dollimore argues, for instance, that "the society of Lear is structured in such a way that to wait for shared experience to generate justice is to leave it too late. Justice is too important to be entrusted to empathy" (192). Although the Gospels condemn the moral chaos of the world, where the princes and "they that 
are great" exercise dominion over the biblical anawim who bow down under the pressure of poverty, starvation or disease, Marxism rejects Christian doctrine in favour of immediate, revolutionary change. Most revolutions legitimize drumhead trials. In the face of outright injustice, any injunction to patience about the presence of evil in this world, such as the one included in the biblical parable of the wheat and tares (Matt. 13:24-43), is considered as offensive toward the victims of mistreatment. Christians accept the prospect of a life-long waiting for justice; an earnest revolutionary does not believe in divine justice, providence, or the Day of Judgment. So in Dollimore's account, Christian mercy, pity (eleos) and forgiveness always come too late. They are belated, insufficient, and therefore deeply unsatisfactory gestures. And yet, as has been noted, Shakespeare's Gloucester quotes Aquinas on charity, not Karl Marx on proletarian revolution. Although the call for social justice is clearly a vital issue in King Lear, the play is principally an apology for the kind of love and forgiveness embodied in the sacrifice of Jesus Christ, which Christians regard as an all-sufficient satisfaction for the sins of humankind.

\section{LOVE TO THE END}

The connection between King Lear and the story of Christ's Passion has been recognized by many critics. Stanley Cavell stated that Cordelia resembles Christ at the crucifixion (73). Jan Kott interpreted Shakespeare's play as a foreshadowing of the absurdist "mockery of all eschatologies," comparing King Lear with Samuel Beckett's Endgame (116). Although Kott did not state this explicitly, we should remember that Beckett's play constantly alludes to the drama which took place on Golgotha, the Place of the Skull. We may think, for instance, of the evocation of Christ's words on the Cross, already evident in the first sentence uttered on stage in Endgame ("Finished. It is finished"). We may also note that the setting of the play is a room with two windows which is reminiscent of the interior of a human skull; and the two characters' names indicate the nailing to the cross: Ham points to the hammer, whereas Clove (French: clou), Nell (English: "nail") and Nagg (German: nagel) are the nails. More recently, David K. Anderson argued along similar lines that "the Easterless tragedy of King Lear never moves beyond Golgotha" (279), leaving the characters and the audience in the dark, or perhaps we should rather say, in the grave. Interestingly enough, however, none of these interpretations admits a Christian reading of Shakespeare's play despite drawing parallels with the narrative of Christ's Passion, which in the Christian story leads from Good Friday to the dawn of the Resurrection. 
Taking the play into their own times, these critics assign a lower profile to Shakespeare's treatment of divine love and forgiveness. As I have already argued, I find such readings partial and misleading. There is no doubt that Shakespeare's Lear astonishes us with the apparently absurd death of Cordelia, but the emotional appeal of this ending cannot overshadow other important elements present in the final act of the play. When Lear enters the stage with the body of Cordelia in his arms, Kent poses a question which may be understood as an ironic, meta-textual comment on Shakespeare's departure from other versions of the story: "Is this the promised end?" Edgar echoes Kent's anguish, but interprets the mention of "the promised end" as referring to the end of times described in the New Testament Book of Revelation. He asks: "Or image of that horror?" Finally, Albany, who alone has not abandoned his faith in divine justice, cries out to heaven for vengeance: "Fall, and cease" (5.3.262-264). The fact that a little earlier Goneril's and Regan's bodies were brought on stage-an arrangement without parallel in the entire Shakespeare corpus-points to the vision of Doomsday conveyed in the Book of Revelation, and foreshadowed in St. Paul's appeal to Timothy: "I charge thee therefore before God, and the Lord Jesus Christ, who shall judge the living and the dead at his appearing and his kingdom" (4:1). What seems particularly striking in this scene is the "freezing" of action and movement, as if we were really witnesses to "the end of time," since time entails movement and change. Yet although this grim tableau mort - for it hardly deserves to be called tableau vivanthas little to do with the ultimate triumph of good over evil envisioned in the Book of Revelation, since the innocent perish together with the wicked, the promise of divine justice is not absent from the play.

Of course, it is only natural that at the end of the play we, like Lear, hope against hope to see Cordelia live, speak and smile again thanks to some fortuitous "chance." But while we would prefer a happy ending, Shakespeare's conclusion proves entirely appropriate for this play about love and forgiveness. Nor is it entirely devoid of hope, although this hope has nothing to do with facile and short-lived consolation. We are confronted with the memory of the hour when Jesus cried from the cross: "God, my God, why hast thou forsaken me?" (Matt. 27:46); the Son felt abandoned by the Father and the gaping wound opened in His heart. When the old king realizes that his daughter cannot be brought back to life, he utters words which sound like the dirge of funeral bells: "O Thou'lt come no more. / Never, never, never" (5.3.306-307). In the Folio version the word "never" is repeated five times, in a possible allusion to the five gashes made in Christ's hands, feet and side. R. A. Foakes asserts that the repetition of "never," which fills the entire line, brings Lear and the audience "to face death not only as the loss of all that is worth cherishing, 
but as utter oblivion" (78). Yet it might also be understood as reminding us of the Passion story, in which death on the cross was not the last word.

The playwright's engagement with the mystery of the crucifixion prompts us to take a brief detour into the realm of theology, which may help us move beyond the emotional appeal of the tragedy and overcome the myopic scepticism that excludes or even denies its eschatological dimension. In Catherine of Siena's Dialogue, we find a passage which links Christ's death on the cross to the mystery of unlimited divine charity. When the Seraphic Virgin implores Christ to tell her why he permitted his side to be "pierced and parted," her divine Interlocutor responds: "My longing for humankind was infinite, but the actual deed of bearing pain and torment was finite and could not show all the love I had. This is why I wanted you to see my inmost heart, so that you could see that I loved you more than finite suffering could show" (138). As Hans-Urs von Balthasar's argues, the decisive element in this vision is the "final, limitless, divine wound, a bleeding that pulses with life from the other side of death" (63).

Shakespeare included an allusion to the pierced side of Jesus at the crucifixion (John 19:34-37) in Act 4, when Edgar, disguised as Poor Tom, expresses his pity towards the old king wandering on the heath with the sad exclamation "O thou side-piercing sight!" (4.6.85) (McDonald 158), and it has been pointed out that "Lear's empathetic defence of Tom ... matches the allegory of the Passion in Southwell Spiritual Exercises" (Lanier Reid 73). Edgar's name, composed of the Old English words ead, "rich," and gar, "spear," likewise brings to mind the holy spear that pierced the side of Jesus after his death on the cross. ${ }^{2}$ Viewed in the light of Balthasar's reflection concerning divine love, such subtle hints in the play to the tragedy of the cross prompt us to take another look at the tableau at the end of Shakespeare's play which some critics have associated with visual portrayals of Christ's Passion. Katharine Goodland has argued that Shakespeare may have had the Pietà in mind when he presented Lear with the body of Cordelia in his arms (47-74, cf. Young 272). In Christian faith, however, the cross is not a token of death, but a symbol of love to the end. It reminds us that death was not the end of God's compassionate love. Disallowing a superficial understanding of divine justice, the apparently incomprehensible ending of King Lear points to the love symbolized by the cross. The visual allusion to the Cross as a symbol of love, forgiveness and reconciliation allows us to see glimpses of hope in the apparently hopeless world of King Lear. Yet instead of presenting us with a straightforward morality play about the necessity of forgiving, the

2 I am grateful to Fr. Norbert Lis OP for his illuminating comments on Edgar's role in the play. 
playwright confronts his audiences with a love which cannot be embodied on stage because any attempt to represent it would verge on idolatry. This love embraces us, though we cannot grasp it. It lives, breathes, suffers and bleeds for us, endlessly. King Lear can also be read as an apology for radical, endless forgiveness—offered "seventy times seven" (Matt. 18:21)—which transcends the mercantile exchange expressed in the formula "measure for measure," and the retributive logic of tit for tat. The play shows that it is always just and possible to forgive. It is just and good to love genuinely, entirely, "to the end."

\section{Works Cited}

Anderson, David K. "The Tragedy of Good Friday: Sacrificial Violence in King Lear." English Literary History, vol. 78, no. 2, Summer 2011, pp. 259-86. https://doi.org/10.1353/elh.2011.0018

Battenhouse, Roy Wesley, and Marian Battenhouse. Shakespeare's Christian Dimension. Indiana UP, 1994.

Beckett, Samuel. Endgame. Faber \& Faber, 2009.

Cantor, Paul A. "What Cause of Thunder." King Lear. New Critical Essays, edited by Jeffrey Kahn, Routledge, 2008, pp. 231-52. https://doi. org/10.4324/9780203090084

Catherine of Siena. The Dialogue. Translated by Susanne Noffke O.P. Paulist, 1980.

Cavell, Stanley. Disowning Knowledge in Seven Plays of Shakespeare. Cambridge UP, 2003. https://doi.org/10.1017/CBO9781139165129

Danby, John Francis. Shakespeare's Doctrine of Nature: A Study of King Lear. Faber \& Faber, 1949.

Dollimore, Jonathan. Radical Tragedy. Religion, Ideology and Power in the Drama of Shakespeare and His Contemporaries. U of Chicago P, 1984.

Foakes, R. A., editor. King Lear, by William Shakespeare, AS/Thomson Learning, 2005.

Goodland, Katharine. "Inverting the Pietà in Shakespeare's King Lear." Marian Moments in Early Modern British Drama, edited by Regina Bucolla and Lisa Hopkins, Ashgate, 2007, pp. 47-74. https://doi. org/10.4324/9781315593890-4

Kott, Jan. Shakespeare Our Contemporary. Translated by Bolesław Taborski. Methuen, 1967. https://doi.org/10.2307/1125124

Kronenfeld, Judy. King Lear and the Naked Truth. Rethinking the Language of Religion and Resistance. Duke UP, 1998.

Lanier Reid, Robert. Shakespeare's Tragic Form: Spirit in the Wheel. U of Delaware P/Associated UP, 2000. 
Marion, Jean-Luc. Prolegomena to Charity. Translated by Stephen E. Lewis. Fordham UP, 2002.

Matthews, Richard. "Edmund's Redemption in King Lear." Shakespeare Quarterly, vol. 26, no. 1, Winter 1975, pp. 25-29. https://doi. org/10.2307/2869263

McDonald, Mark Allen. Shakespeare's King Lear with the Tempest: The Discovery of Nature and the Recovery of Classical Natural Right. UP of America, 2004.

Schwartz, Regina. Loving Justice, Living Shakespeare. Oxford UP, 2016. https://doi.org/10.1093/acprof:oso/9780198795216.001.0001

Schwartz, Regina. "Revenge, Forgiveness, and Love." Love and Forgiveness for a More Just World, edited by Hent de Vries and Nils F. Schott, Columbia UP, 2015, pp. 43-71. https://doi.org/10.7312/ columbia/9780231170222.003.0005

Shakespeare, William. The Tragedy of King Lear. Edited by R. A. Foakes. AS/Thomson Learning, 2005.

Snyder, Susan. "King Lear and the Prodigal Son." Shakespeare Quarterly, vol. 17, no. 4, Autumn 1966, pp. 361-69. https://doi. org/10.2307/2867910

Summers, Joseph Holmes. Dreams of Love and Power. On Shakespeare's Plays. Clarendon, 1984.

The Bible. King James Bible Online, https://www.kingjamesbibleonline. org, accessed 2021.

Von Balthasar, Hans-Urs. You Have Words of Life Eternal: Scripture Meditation. Translated by Dennis Martin. Ignatius, 2004.

Wilson Knight, G. The Wheel of Fire. Interpretations of Shakespearean Tragedy. Routledge, 1989.

Young, R. V. "Hope and Despair in King Lear. The Gospel and Crisis of the Natural Law." King Lear. New Critical Essays, edited by Jeffrey Kahn, Routledge, 2008, pp. 253-77. https://doi.org/10.4324/9780203090084

\section{Małgorzata Grzegorzewska is Professor} of English Literature in the Institute of English Studies at the University of Warsaw. She is a specialist in Renaissance literature and drama, and has published extensively on Shakespeare in Polish and English, as well as the metaphysical poets. Her works explore the connections among literature, theology and philosophy. Among her works is George Herbert and PostPhenomenology. A Gift for Our Times (Peter Lang, 2016); she co-edited, with Mark S. Burrows and Jean Word Poetic Revelations (Routledge, 2017). https://orcid.org/0000-0002-0194-2919

m.grzegorzews2@uw.edu.pl 